\title{
MUTU YOGHURT SUSU KUDA LIAR DENGAN PENAMBAHAN EKSTRAK KAYU MANIS PADA BERBAGAI KONSENTRASI
}

\author{
[The Quality of Yoghurt Wild Horse Milk with the Addition of Sweet Wood Extract in \\ Various Concentrations]
}

\author{
Siti Sarah Marnianti, Nazaruddin, Siska Cicilia* \\ Fakultas Teknologi Pangan dan Agroindusti, Universitas Mataram, Nusa Tenggara Barat \\ Jl. Majapahit No.58 Mataram \\ *E-mail: siskacicilia@unram.ac.id
}

Diterima 15 Maret 2021 / Disetujui 17 April 2021

\begin{abstract}
Objective of this research was to find out the quality of y Sumbawa wild horse milk yogurt added with cinnamon extract at various concentrations. This research used a single factor completely randomized design $(C R D)$ with a concentration of cinnamon extract $(P)$ consisting of 6 treatments, i.e. P1 (0\%), P2 (2\%), P3 (4\%), P4 (6\%), P5 (8\%) and P6 (10\%). The parameters observed were chemical quality (antioxidant activity, protein content and $\mathrm{pH}$ value), physical quality (viscosity and color), microbiological quality (total LAB) and organoleptic quality (color, aroma, taste, and thickness). The data from the observations were analyzed using Anova with a real level of 5\% using Costat software. If there was a significant difference, a further Orthogonal Polynomial test carried out for chemical quality, HSD at a significant level of 5\% for organoleptic quality, and microbiological quality were analyzed descriptively. The results showed that the addition of cinnamon extract affected the quality of the yogurt. The higher the concentration of cinnamon extract, the higher the antioxidant activity, protein content, viscosity, color, total $L A B$ and the lower the $\mathrm{pH}$ value. The best quality of yogurt is produced with the addition of $10 \%$ cinnamon extract with $35.76 \%$ of antioxidant activity, 3.85\% of protein content, 4.65 of $\mathrm{pH}$ value, $8,2 \times 109 \mathrm{CFU} / \mathrm{ml}$ of $L A B$ total in accordance with the quality requirements of yoghurt based on SNI 2981: 2009 as well as organoleptics acceptable to the panelists.
\end{abstract}

Keywords: cinnamon extract, milk, Sumbawa's wild horse, yoghurt.

\section{ABSTRAK}

Penelitian ini bertujuan untuk mengetahui mutu yoghurt susu kuda liar Sumbawa yang ditambahkan dengan ekstrak kayu manis pada berbagai konsentrasi. Rancangan penelitian menggunakan Rancangan Acak Lengkap (RAL) faktor tunggal adalah konsentrasi ekstrak kayu manis $(P)$ yang terdiri atas 6 perlakuan, yaitu P1 $(0 \%)$, P2 (2\%), P3 (4\%), P4 (6\%), P5 (8\%) dan P6 (10\%) yang diulang sebanyak 3 kali. Parameter yang diamati yaitu mutu kimia (aktivitas antioksidan, kadar protein dan nilai $\mathrm{pH}$ ), mutu fisik (viskositas dan warna), mutu mikrobiologi (total BAL) dan mutu organoleptik (warna, aroma, rasa, dan kekentalan). Data hasil pengamatan dianalisis menggunakan Anova dengan taraf nyata $5 \%$ dengan menggunakan software Costat. Apabila terdapat perbedaan nyata, maka dilakukan uji lanjut Polynomial Orthogonal untuk mutu kimia, uji lanjut BNJ pada taraf nyata $5 \%$ untuk mutu organoleptik, dan mutu mikrobiologis dianalisis secara deskriptif. Hasil penelitian menunjukkan bahwa penambahan ekstrak kayu manis mempengaruhi mutu yoghurt. Semakin tinggi konsentrasi ekstrak kayu manis, maka semakin meningkat aktivitas antioksidan, kadar protein, viskositas, warna, total BAL serta semakin rendah nilai $\mathrm{pH}$. Mutu yoghurt terbaik dihasilkan dengan penambahan $10 \%$ ekstrak kayu manis dengan aktivitas antioksidan 35,76\%; kadar protein 3,85\%; nilai pH 4,65; total $\mathrm{BAL} 8,2 \times 10^{9} \mathrm{CFU} / \mathrm{ml}$ yang sesuai dengan persyaratan mutu yoghurt berdasarkan SNI 2981:2009 serta organoleptik yang dapat diterima oleh panelis.

Kata kunci: ekstrak kayu manis, kuda liar Sumbawa, susu, yoghurt.

\section{PENDAHULUAN}

Kuda liar Sumbawa merupakan salah satu komoditi ternak unggulan dari Kabupaten Sumbawa. Menurut Badan Pusat Statistik (BPS) pada tahun 2014, jumlah kuda yang diternak di Kabupaten Sumbawa mencapai 20.206 ekor. Kuda liar Sumbawa khususnya kuda liar betina diternak dengan tujuan untuk reproduksi dan menghasilkan susu yang di pasaran dikenal dengan nama susu kuda liar Sumbawa. Susu kuda diketahui mengandung nilai gizi berupa lemak $1,09 \%$, protein 2,8 $4,0 \%$, laktosa (karbohirat) 6,26\%, beragam vitamin seperti $A, B, C$ dan juga $E$, kalium, kalsium, magnesium, dan zat besi yang 
hampir mirip dengan susu sapi (Rachman dkk, 1992). Pemanfaatan susu kuda liar selama ini adalah diminum dalam kondisi segar dan diolah menjadi permen susu kuda liar. Namun, rasa asam dan aroma amis pada susu kuda liar Sumbawa menyebabkan nilai dan daya terima pada konsumen menjadi rendah. Oleh karena itu untuk mengurangi rasa asam dan aroma yang amis serta menambah nilai tambah dan keanekaragaman produk, susu kuda liar Sumbawa dapat diolah menjadi yoghurt.

Yoghurt merupakan suatu produk olahan hasil fermentasi dari susu yang memiliki rasa asam yang spesifik serta memiliki kelebihan dibandingkan susu segar antara lain nilai gizinya yang lebih tinggi, mengandung mikroba probiotik yang menguntungkan bagi mikroflora dalam saluran pencernaan, bermanfaat bagi penderita lactose intolerance yang merupakan gejala malabsorbsi laktosa, dapat menurunkan kadar kolesterol darah, menjaga kesehatan lambung dan mencegah penyakit kanker saluran pencernaan (Legowo dkk, 2009). Susilorini dan Sawitri (2007) menyatakan bahwa yoghurt merupakan produk olahan susu hasil fermentasi dari Bakteri Asam Laktat (BAL) yaitu Lactobacillus bulgaricus dan Streptococcus thermophillus yang hidup bersimbiosis mutualisme dan saling melengkapi.

Menurut Shah (2000) faktor utama keberhasilan proses fermentasi pada produk yoghurt adalah terciptanya suasana asam dengan kondisi pH sekitar 4,5-6 yang merupakan kondisi optimum untuk menstimulir pertumbuhan BAL yaitu $L$. bulgaricus dan $\mathrm{S}$. thermophillus yang juga dapat mempengaruhi mutu yoghurt yang dihasilkan. Semakin optimum kondisi pH pada produk yoghurt maka jumlah BAL yang tumbuh akan semakin meningkat, sehingga akan semakin banyak asam laktat yang terbentuk menyebabkan pH kembali turun dan menyebabkan terbentuknya koagulan kasein sehingga terbentuk gumpalan yoghurt dengan rasa dan flavour yang khas (Indratiningsih $d k k, 2004)$. Menurut penelitian Lindasari dkk
(2013), salah satu senyawa yang dapat memberikan kondisi $\mathrm{pH}$ yang cocok untuk pertumbuhan BAL ialah kayu manis.

Kayu manis (Cinnamomum burmanii) merupakan rempah-rempah dalam bentuk kulit kayu yang biasa dimanfaatkan masyarakat Indonesia sebagai penambah cita rasa masakan dan pembuatan kue karena mengandung sinemaldehida dan minyak atsiri eugenol yang mempunyai rasa pedas dan manis, beraroma wangi serta bersifat hangat (Towaha, 2012). Oleh karena itu, penambahan kayu manis dapat membantu dalam meningkatkan organoleptik terutama pada produk yang memiliki bau amis. Ekstrak kayu manis juga dapat membantu menurunkan $\mathrm{pH}$ karena mengandung asam sinamat yaitu senyawa penanda pada ekstrak kayu manis yang tergolong dalam senyawa fenol dengan bahan dasar berupa fenilalanin dan tirosin yang dapat menurunkan nilai $\mathrm{pH}$ susu sehingga menyediakan lingkungan asam yang sesuai untuk kultur starter BAL.

Menurut penelitian Lindasari dkk (2013) penambahan ekstrak kayu manis sebanyak $5 \%$ pada yoghurt probiotik susu kambing yang diberi pakan campuran karboksilat kering dapat meningkatkan pertumbuhan BAL sebesar 0,8 log $10 \mathrm{CFU} / \mathrm{ml}$. Menurut penelitian Kusumawati (2019) penambahan kayu manis dengan konsentrasi $2 \%$ pada yoghurt probiotik nanas madu dan kayu manis menghasilkan protein sebanyak $1,28 \mathrm{mg} / 100 \mathrm{ml}$, dan lemak sebanyak 2,76 $\mathrm{mg} / 100 \mathrm{ml}$. Putri (2018) menyatakan bahwa penambahan bubuk kulit kayu manis pada mayonnaise kuning telur probiotik dengan konsentrasi $1 \%$ menghasilkan aktivitas antioksidan 77,52\%; pH 3,70; viskositas 9,62 $\mathrm{CP}$; dan total BAL $2 \times 10^{7} \mathrm{CFU} / \mathrm{g}$.

Kayu manis juga dapat bertindak sebagai antioksidan karena mengandung sinemaldehid, eugenol, asam sinamat, katekin, epikatekin, dan senyawa polifenol lain yang menjadikan kayu manis potensial sebagai antioksidan yang bertindak sebagai penstabil radikal bebas yang bekerja dengan cara melengkapi kekurangan elektron radikal bebas dan menghambat terjadinya reaksi berantai 
dari pembentukan radikal bebas (Hastuti dan Rustanti, 2014). Bandara (2011) menyebutkan bahwa kayu manis selain sebagai antioksidan juga memiliki kemampuan antimikroba, antifungi, antivirus, antitumor, penurun tekanan darah, kolesterol dan memiliki senyawa rendah lemak. Menurut Shan et al (2007), kayu manis memiliki efek antibakteri terhadap pertumbuhan Bacillus cereus, Listeria monocytogenes, Staphylococcus aureus, Escherichia coli dan Salmonella anatum.

\section{BAHAN DAN METODE}

\section{Alat dan Bahan}

Bahan-bahan yang digunakan adalah batang kayu manis yang dibeli di Pasar Kebon Roek di daerah Ampenan, susu kuda liar Sumbawa yang diperoleh dari Sumbawa, susu skim, gula pasir (Gulaku, Indonesia), air (Aqua, Indonesia), aquades steril, Cimory, etanol 96\%, larutan $\mathrm{DPPH}$, metanol, $\mathrm{CuSO}_{4}$, $\mathrm{K}_{2} \mathrm{SO}_{4}, \mathrm{HCl}, \mathrm{H}_{3} \mathrm{BO}_{3}$ larutan buffer, $\mathrm{NaOH} 40 \%$, buffer fosfat, media De Man Rogosa and Sharpe Broth (MRSB) (Oxoid, Inggris) dan media De Man Rogosa and Sharpe Agar (MRSA) (Oxoid, Inggris). Alat-alat yang digunakan adalah cabinet dryer, blender, evaporator, spektrofotometer, colorimeter, viscometer, timbangan analitik (ABJ, Jerman), inkubator (Memmert, Jerman), magnetic stirer, pH meter (Omega, Amerika), waterbath, ATK dan peralatan laboratorium lainnya.

\section{Metode}

Metode penelitian ini adalah metode eksperimental dengan Rancangan Acak Lengkap (RAL) faktor tunggal adalah konsentrasi ekstrak kayu manis $(P)$ yang terdiri atas 6 perlakuan, yaitu P1 $(0 \%), \mathrm{P} 2$ (2\%), P3 (4\%), P4 (6\%), P5 (8\%) dan P6 $(10 \%)$. Parameter yang diamati yaitu mutu kimia (aktivitas antioksidan, kadar protein dan nilai pH), mutu fisik (warna), mutu mikrobiologi (total BAL) dan mutu organoleptik (warna, aroma, rasa, dan kekentalan). Data hasil pengamatan dianalisis menggunakan Anova dengan taraf nyata $5 \%$ dengan menggunakan software Costat. Apabila terdapat perbedaan nyata, maka dilakukan uji lanjut menggunakan Polynomial Orthogonal untuk mutu kimia, uji lanjut BNJ untuk mutu organoleptic sedangkan mutu mikrobiologis dianalisis secara deskriptif.

\section{Pelaksanaan Penelitian}

\section{Proses Ekstraksi Kayu Manis}

Tahapan ekstraksi kayu manis meliputi sortasi, pencucian, perajangan, pengeringan menggunakan cabinet dryer pada suhu $50^{\circ} \mathrm{C}$ selama 3 jam, penghalusan, pengayakan, perendaman menggunakan etanol $96 \%$ dengan perbandingan etanol dengan simplisia $3: 1$, penyaringan, dan pemekatan menggunakan evaporator dengan suhu $40^{\circ} \mathrm{C}$ selama 2 jam.

\section{Pembuatan Yoghurt Susu Kuda Liar Sumbawa}

Pembuatan yoghurt susu kuda liar Sumbawa diawali dengan pembuatan media MRSB, kultur propagasi, kultur induk, dan starter siap pakai. Pencampuran I yaitu pencampuran susu kuda liar sebanyak $300 \mathrm{~mL}$ dengan $5 \%$ gula dan $5 \%$ susu skim, pasteurisasi dengan suhu $70^{\circ} \mathrm{C}$ selama 15 menit, penurunan suhu hingga mencapai suhu $37^{\circ} \mathrm{C}$, pencampuran II yaitu penambahan ekstrak kayu manis dengan konsentrasi $0 \%$, $2 \%, 4 \%, 6 \%$, $8 \%$, dan $10 \%$ ke dalam campuran susu kuda liar dan susu skim, inokulasi kultur BAL dengan menambahkan starter 3\% kultur starter siap pakai kemudian diinkubasi pada suhu $37^{\circ} \mathrm{C}$ selama 15 jam dengan tujuan agar BAL dapat melakukan proses fermentasi dengan baik. Setelah diinkubasi selama 15 jam kemudian dihasilkan yoghurt dengan penambahan ekstrak kayu manis.

\section{Parameter Pengamatan}

Parameter yang diamati dalam penelitian ini yaitu parameter kimia, fisik, mikrobiologi, dan organoleptik. Parameter kimia meliputi pengujian, kadar protein, $\mathrm{pH}$, dan aktivitas antioksidan, parameter fisik meliputi uji warna, parameter mikrobiologi meliputi uji total BAL, dan parameter organoleptik yaitu rasa dan aroma (hedonik). 


\section{HASIL DAN PEMBAHASAN}

Pada bab ini akan dibahas mengenai pengaruh perlakuan terhadap parameter uji. Hasil sigifikansi dan uji lanjut masing-masing parameter dapat dilihat pada Tabel $1-7$.

Tabel 1. Signifikansi Hasil Pengamatan Pengaruh Konsentrasi Ekstrak Kayu Manis terhadap Aktivitas Antioksidan, Kadar Protein, dan pH Yoghurt Susu Kuda Liar Sumbawa

\begin{tabular}{lccc}
\hline \multicolumn{1}{c}{ Parameter } & $\begin{array}{c}\text { F } \\
\text { hitung }\end{array}$ & $\begin{array}{c}\text { F } \\
\text { tabel }\end{array}$ & Signifikansi \\
\hline Aktivitas & 38,14 & 0,99 & $\mathrm{~S}$ \\
Antioksidan & & & \\
Kadar Protein & 10,11 & 0,99 & $\mathrm{~S}$ \\
pH & 106,57 & 0,99 & $\mathrm{~S}$ \\
\hline $\begin{array}{l}\text { Keterangan: S = Signifikan (Berbeda Nyata), NS = Non- } \\
\text { Signifikan (Tidak Berbeda Nyata) }\end{array}$
\end{tabular}

Tabel 2. Hasil Uji Lanjut Polynomial Orthogonal Aktivitas Antioksidan, Kadar Protein dan pH Yoghurt Susu Kuda Liar Sumbawa pada Berbagai Konsentrasi Ekstrak Kayu Manis

\begin{tabular}{llc}
\hline \multicolumn{1}{c}{ Parameter } & Respon & Signifikansi \\
\hline Aktivitas Antioksidan & Linier & $\mathrm{S}$ \\
\multirow{3}{*}{ Kadar Protein } & Kuadratik & NS \\
& Linier & $\mathrm{S}$ \\
$\mathrm{pH}$ & Kuadratik & NS \\
& Linier & $\mathrm{S}$ \\
& Kuadratik & NS \\
\hline
\end{tabular}

Keterangan: S = Signifikan (Berbeda Nyata), NS = NonSignifikan (Tidak Berbeda Nyata)

Tabel 3. Signifikansi Hasil Pengamatan Pengaruh Konsentrasi Ekstrak Kayu Manis terhadap ${ }^{\circ}$ Hue dan Lightness Yoghurt Susu Kuda Liar Sumbawa

\begin{tabular}{lccc}
\hline Parameter & $\begin{array}{c}\mathbf{F} \\
\text { hitung }\end{array}$ & $\begin{array}{c}\text { F } \\
\text { tabel }\end{array}$ & Signifikansi \\
\hline Hue & 2318,92 & 0,99 & $\mathrm{~S}$ \\
Lightness & 56,47 & 0,99 & $\mathrm{~S}$ \\
\hline \multicolumn{4}{l}{ Keterangan: S = Signifikan (Berbeda Nyata), NS = Non- } \\
\multicolumn{2}{l}{ Signifikan (Tidak Berbeda Nyata) }
\end{tabular}

Tabel 4. Hasil Uji Lanjut Polynomial Orthogonal oHue dan Lightness Yoghurt Susu Kuda Liar Sumbawa pada Berbagai Konsentrasi ekstrak kayu manis

\begin{tabular}{llc}
\hline \multicolumn{1}{c}{ Parameter } & \multicolumn{1}{c}{ Respon } & Signifikansi \\
\hline 'Hue & Linier & S \\
& Kuadratik & NS \\
\hline Lightness & Linier & S \\
& Kuadratik & NS \\
\hline $\begin{array}{l}\text { Keterangan: S = Signifikan (Berbeda Nyata), NS = Non- } \\
\text { Signifikan (Tidak Berbeda Nyata) }\end{array}$
\end{tabular}

Tabel 5. Signifikansi Hasil Pengamatan Pengaruh Konsentrasi Ekstrak Kayu Manis terhadap Total BAL Yoghurt Susu Kuda Liar Sumbawa

\begin{tabular}{|c|c|c|c|}
\hline Parameter & $\begin{array}{c}F \\
\text { hitung }\end{array}$ & $\begin{array}{c}\mathbf{F} \\
\text { tabel }\end{array}$ & Signifikansi \\
\hline Total BAL & 0,54 & 0,99 & NS \\
\hline
\end{tabular}

Tabel 6. Signifikansi Pengaruh Konsentrasi Ekstrak Kayu Manis terhadap Organoleptik Yoghurt Susu Kuda Liar Sumbawa

\begin{tabular}{cccc}
\hline Parameter & $\begin{array}{c}\mathbf{F} \\
\text { hitung }\end{array}$ & $\begin{array}{c}\mathbf{F} \\
\text { tabel }\end{array}$ & Signifikansi \\
\hline Aroma & 0,72 & 2,29 & NS \\
Rasa & 2,05 & 2,29 & NS \\
\hline Keterangan: $\mathrm{S}=$ Signifikan (Berbeda Nyata), NS = Non- \\
Signifikan (Tidak Berbeda Nyata)
\end{tabular}

Tabel 7. Hasil Uji Lanjut BNJ 5\% Analisis Pengaruh Konsentrasi Ekstrak Kayu Manis terhadap Rasa dan Aroma (Hedonik) Yoghurt Susu Kuda Liar Sumbawa

\begin{tabular}{ccc}
\hline \multirow{2}{*}{$\begin{array}{c}\text { Perlakuan } \\
\text { (Konsentrasi } \\
\text { Ekstrak Kayu } \\
\text { Manis) }\end{array}$} & \multicolumn{2}{c}{ Purata } \\
\cline { 2 - 3 } & & Rasoma \\
\hline P1 $(0 \%)$ & $4,25^{\mathrm{a}}$ & $2,55^{\mathrm{b}}$ \\
P2 $(2 \%)$ & $2,85^{\mathrm{b}}$ & $3^{\mathrm{ab}}$ \\
P3 $(4 \%)$ & $1,8^{\mathrm{c}}$ & $3,35^{\mathrm{ab}}$ \\
P4 $(6 \%)$ & $1,65^{\mathrm{c}}$ & $3,45^{\mathrm{ab}}$ \\
P5 $(8 \%)$ & $1,75^{\mathrm{c}}$ & $3,5^{\mathrm{ab}}$ \\
P6 (10\%) & $1,9^{\mathrm{c}}$ & $3,6^{\mathrm{a}}$ \\
\hline BNJ 5\% & 0,80 & 1,16 \\
\hline Keterangan: Angka-angka yang dikuti oleh huruf-huruf \\
yang sama pada kolom yang sama menunjukkan tidak ada \\
perbedaan nyata pada taraf nyata 5\%.
\end{tabular}

\section{Aktivitas Antioksidan}

Antioksidan merupakan suatu senyawa yang berperan dalam menghambat oksidasi yang diperantarai oksigen. Aktivitas antioksidan merupakan kemampuan senyawa antioksidan untuk menangkal radikal bebas. Senyawa antioksidan memegang peranan penting dalam pertahanan tubuh terhadap penyakit. Hal tersebut disebabkan senyawa antioksidan dapat mencegah pengaruh buruk yang disebabkan oleh senyawa radikal bebas (Percival, 1998). Hubungan konsentrasi ekstrak kayu manis terhadap aktivitas antioksidan yoghurt susu kuda liar Sumbawa dapat dilihat pada Gambar 1. 


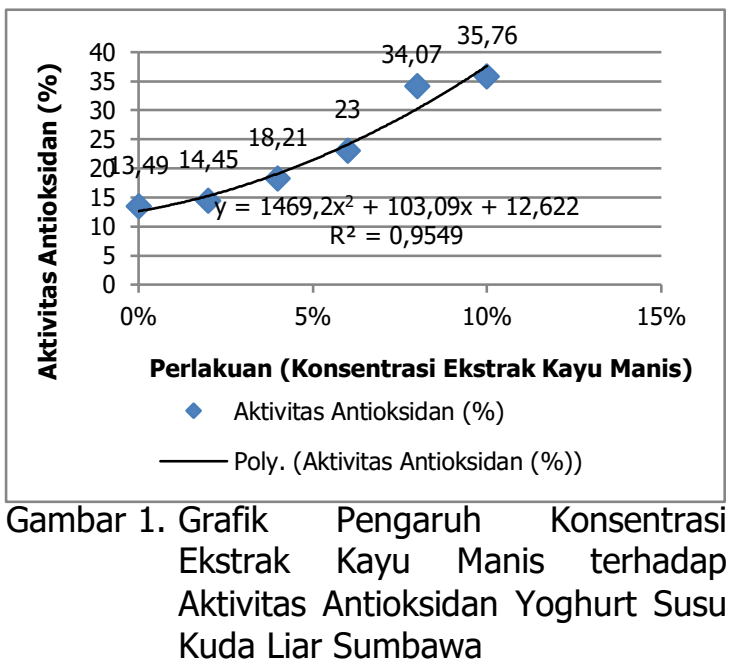

Gambar 1 menunjukkan bahwa konsentrasi ekstrak kayu manis memberikan pengaruh yang berbeda nyata terhadap aktivitas antioksidan yoghurt susu kuda liar Sumbawa dengan pola regresi linear dengan persamaan $y=1469 x^{2}+103,0 x+12,62$ dengan koefisien determinan $\left(R^{2}\right)=0,954$. Nilai 1469 menunjukan arah regresi linear yaitu nilai positif. Nilai positif pada pola regresi menunjukkan hubungan yang positif antara perlakuan konsentrasi ekstrak kayu manis dengan aktivitas antioksidan yoghurt susu kuda liar Sumbawa yang dihasilkan. Hal ini menunjukkan bahwa ekstrak kayu manis dengan konsentrasi tertentu, maka dapat meningkatkan aktivitas antioksidan yoghurt susu kuda liar Sumbawa. Nilai 12,62 menunjukkan konstanta, sehingga pada nilai (x) atau konsentrasi ekstrak kayu manis $=0$, maka aktivitas antioksidan yoghurt susu kuda liar Sumbawa adalah sebesar $12,62 \%$. Nilai koefesien determinan $\left(R^{2}\right)$ diperoleh sebesar 0,954 yang berarti bahwa $95,4 \%$ aktivitas antioksidan yoghurt susu kuda liar Sumbawa dipengaruhi oleh adanya konsentrasi ekstrak kayu manis dan sebagian kecil yaitu sebesar $4,6 \%$ merupakan faktor lain yang mempengaruhi aktivitas antioksidan yoghurt susu kuda liar Sumbawa.

Aktivitas antioksidan yoghurt susu kuda liar Sumbawa meningkat seiring dengan peningkatan konsentrasi ekstrak kayu manis, yaitu dengan nilai tertinggi pada konsentrasi ekstrak kayu manis $10 \%$. Hal ini sejalan dengan penelitian Apriliani dkk (2019), bahwa penambahan kayu manis dapat meningkatkan aktivitas antioksidan minuman sari buah alpukat yang dihasilkan. Hal ini disebabkan karena kayu manis memiliki beberapa kandungan senyawa antioksidan yaitu sinemaldehid $(60,17 \%)$, eukaliptol dan eugenol $(17,62 \%)$, kumarin $(13,39 \%)$, fenol, terpenoid, dan saponin (Wang et al (2009) dalam Hasan (2011)). Hastuti dan Rustanti (2014) menyatakan bahwa sinemaldehid merupakan senyawa fitokimia yang paling dominan pada kayu manis yang dapat berperan sebagai antioksidan. Dengan demikian, semakin banyak ekstrak kayu manis yang ditambahkan, maka aktivitas antioksidan yoghurt susu kuda liar Sumbawa yang dihasilkan semakin meningkat.

\section{Kadar Protein}

Kadar protein bahan pangan umumnya digunakan sebagai salah satu cara untuk mengukur mutu bahan pangan karena protein merupakan suatu zat yang penting bagi kehidupan manusia (Sudarmadji dkk, 2007). Protein merupakan zat makanan yang sangat penting bagi tubuh karena selain berfungsi sebagai bahan bakar dalam tubuh juga berfungsi sebagai zat pembangun dan pengatur. Fungsi utama protein bagi tubuh adalah untuk membentuk jaringan baru serta mempertahankan jaringan yang telah ada (Winarno, 1997).

Yoghurt merupakan salah satu bahan pangan sumber protein, sehingga protein menjadi salah satu komponen penting pada yoghurt. Hal ini tidak terlepas dari peran BAL pada yoghurt, selama proses fermentasi susu menjadi yoghurt terjadi sintesis vitamin B kompleks khususnya thiamin (vitamin B1) dan riboflavin (vitamin B2), serta beberapa asam amino penyusun protein (Surajudin dkk., 2005). Hubungan konsentrasi ekstrak kayu manis dengan kadar protein yoghurt susu kuda liar Sumbawa dapat dilihat pada Gambar 2.

Gambar 2 menunjukkan bahwa konsentrasi ekstrak kayu manis memberikan pengaruh yang berbeda nyata terhadap kadar 
protein yoghurt susu kuda liar Sumbawa dengan pola regresi linear dengan persamaan $y=21,83 x^{2}+7,469 x+2,861$ dengan koefisien determinan $\left(R^{2}\right)=0,966$. Nilai 21,83 menunjukkan arah regresi linear yaitu nilai positif. Nilai positif pada pola regresi menunjukkan hubungan yang positif antara perlakuan konsentrasi ekstrak kayu manis dengan kadar protein yoghurt susu kuda liar Sumbawa yang dihasilkan. Hal ini menunjukkan bahwa ekstrak kayu manis dengan konsentrasi tertentu dapat meningkatkan kadar protein yoghurt susu kuda liar Sumbawa. Nilai 2,861 menunjukkan konstanta, sehingga pada nilai $(x)$ atau konsentrasi ekstrak kayu manis $=0$, maka kadar protein yoghurt susu kuda liar Sumbawa adalah sebesar 28,61\%. Nilai koefisien determinan $\left(R^{2}\right)$ diperoleh sebesar 0,966 yang berarti bahwa $96,6 \%$ kadar protein yoghurt susu kuda liar Sumbawa dipengaruhi oleh adanya konsentrasi ekstrak kayu manis dan sebagian kecil yaitu sebesar 3,4\% merupakan faktor lain yang mempengaruhi kadar protein yoghurt susu kuda liar Sumbawa.

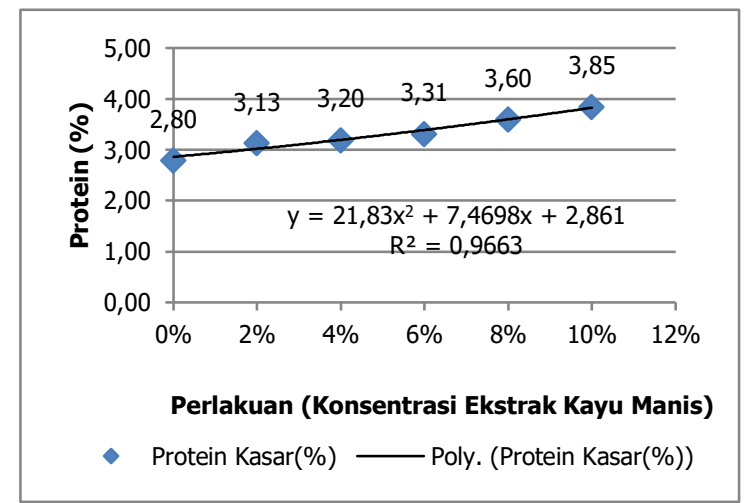

Gambar 2. Grafik Pengaruh Konsentrasi Ekstrak Kayu Manis terhadap Kadar Protein Yoghurt Susu Kuda Liar Sumbawa

Peningkatan kadar protein yoghurt susu kuda liar Sumbawa terjadi seiring dengan meningkatnya konsentrasi ekstrak kayu manis yang digunakan. Hal ini disebabkan karena kayu manis mengandung senyawa kimia berupa sinemaldehid yang memiliki senyawa turunan berupa asam organik yaitu asam sinamat yang berperan dalam menurunkan $\mathrm{pH}$ pada yoghurt. Hastuti dan Rustanti (2014) menyatakan bahwa ekstrak kayu manis memiliki pH 4,25 yang berasal dari senyawa kimia berupa sinemaldehid sehingga penambahan dengan konsentrasi yang semakin tinggi akan memberikan suasana yang semakin asam yang dibutuhkan untuk pertumbuhan BAL. Semakin optimum kondisi lingkungan pertumbuhan BAL, maka akan terjadi peningkatan pertumbuhan BAL.

Menurut Herawati dan Wibawa (2011) yang menyatakan bahwa semakin banyak jumlah BAL dalam yoghurt, maka akan semakin tinggi kandungan proteinnya, karena sebagian besar komponen penyusun BAL adalah protein. Senada dengan Winarno dan Fernandez (2007) yang mengatakan bahwa materi sel BAL tersusun dari protein. Fardiaz (1993) menyatakan bahwa sel BAL memiliki lapisan pembungkus sel berupa membran plasma dan dinding sel yang mengandung protein dan polisakarida. Senada dengan Purwitasari dkk (2004) adanya pertambahan jumlah mikroorganisme dapat meningkatkan kadar protein karena peran mikroorganisme sebagai Protein Sel Tunggal atau Single Cell Protein (SCP). SCP merupakan istilah yang digunakan untuk protein kasar atau murni yang berasal dari mikroorganisme bersel satu atau banyak yang sederhana, seperti bakteri, khamir (yeast), jamur, ganggang, dan protozoa (Whitaker, 1977). Berdasarkan Gambar 16, terlihat bahwa kadar protein yoghurt susu kuda liar Sumbawa dengan konsentrasi ekstrak kayu manis sebesar $0 \%$ hingga $10 \%$ memenuhi syarat menurut Standar Nasional Indonesia (SNI) nomor (SNI) 2981:2009 yang menyatakan bahwa kadar protein minimal untuk produk yoghurt ialah sebesar $2,7 \%$.

\section{Derajat Keasaman (pH)}

Derajat keasaman digunakan untuk menyatakan tingkat keasaman atau kebasaan yang dimiliki oleh suatu bahan pangan. Nilai $\mathrm{pH}$ merupakan salah satu faktor yang menentukan keberhasilan dalam proses pembuatan yoghurt. Nilai $\mathrm{pH}$ akan memberikan kondisi lingkungan yang optimal 
bagi pertumbuhan dan perkembangan BAL sehingga dapat memudahkan terbentuknya asam laktat untuk membantu mengoptimalkan proses fermentasi yang berlangsung. Hubungan konsentrasi ekstrak kayu manis dengan pH Yoghurt Susu Kuda Liar Sumbawa dapat dilihat pada Gambar 3.

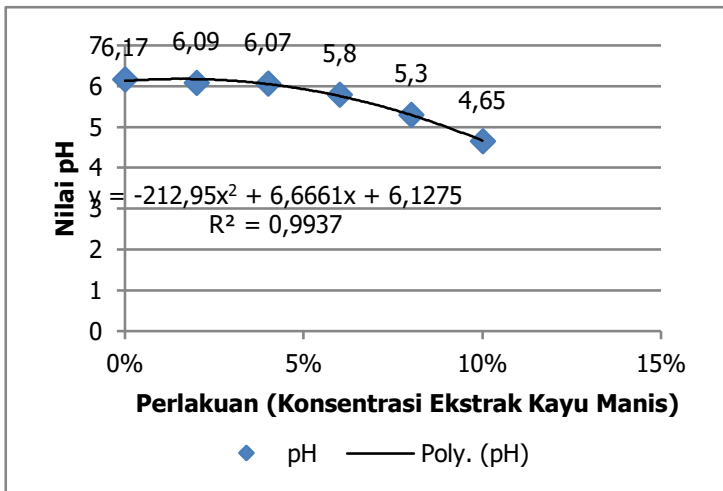

Gambar 3. Grafik Pengaruh Konsentrasi Ekstrak Kayu Manis terhadap pH Yoghurt Susu Kuda Liar Sumbawa

Gambar 3 menunjukkan bahwa konsentrasi ekstrak kayu manis memberikan pengaruh yang berbeda nyata terhadap $\mathrm{pH}$ yoghurt susu kuda liar Sumbawa yang dihasilkan dengan pola regresi linear dengan persamaan $y=-212,9 x^{2}+6,666 x+6,127$ dengan koefisien determinan $\left(R^{2}\right)=0,993$. Nilai $-212,9$ menunjukkan arah regresi linear yaitu nilai negatif. Nilai negatif pada pola regresi menunjukkan hubungan yang negatif antara perlakuan konsentrasi ekstrak kayu manis dengan $\mathrm{pH}$ yoghurt susu kuda liar Sumbawa yang dihasilkan. Hal ini menunjukkan bahwa ekstrak kayu manis dengan konsentrasi tertentu, maka dapat menurunkan $\mathrm{pH}$ yoghurt susu kuda liar Sumbawa. Nilai 6,127 menunjukkan konstanta, sehingga pada nilai $(x)$ atau konsentrasi ekstrak kayu manis $=0$, maka $\mathrm{pH}$ yoghurt susu kuda liar Sumbawa adalah sebesar 6,127 . Nilai koefisien determinan $\left(R^{2}\right)$ yoghurt susu kuda liar Sumbawa diperoleh sebesar 0,993 yang berarti bahwa 99,3\% pH yoghurt susu kuda liar Sumbawa dipengaruhi oleh adanya konsentrasi ekstrak kayu manis dan sebagian kecil yaitu sebesar $0,7 \% \mathrm{pH}$ yoghurt susu kuda liar Sumbawa dipengaruhi oleh faktor lain.

Gambar 3 menunjukkan bahwa semakin tinggi konsentrasi ekstrak kayu manis yang ditambahkan maka $\mathrm{pH}$ yoghurt susu kuda liar Sumbawa semakin menurun, dengan nilai tertinggi pada konsentrasi $0 \%$ sebesar 6,17 , dan nilai terendah pada konsentrasi $10 \%$ sebesar 4,65. Hal ini disebabkan karena ekstrak kayu manis mengandung senyawa kimia berupa sinemaldehid yang bersifat asam sehingga penambahan dengan konsentrasi yang semakin tinggi akan memberikan suasana yang semakin asam (Hastuti dan Rustanti, 2014). Sinemaldehid memiliki senyawa turunan berupa asam organik yaitu asam sinamat yang dapat berperan dalam menurunkan $\mathrm{pH}$ pada yoghurt.

Penurunan juga terjadi disebabkan karena pertumbuhan BAL yang semakin meningkat seiring dengan semakin tinggi konsentrasi ekstrak kayu manis yang ditambahkan sehingga berpengaruh pada produksi asam laktat pada yoghurt. Hal ini sejalan dengan pernyataan Setiarto dkk (2017), bahwa total asam laktat yoghurt dipengaruhi oleh aktivitas kultur bakteri pada starter untuk memfermentasi gula menjadi asam laktat dan sejumlah kecil asam lainnya sehingga semakin tinggi total asam laktat maka $\mathrm{pH}$ akan semakin rendah. Dengan demikian semakin tinggi konsentrasi ekstrak kayu manis dan semakin tinggi total BAL maka nilai $\mathrm{pH}$ semakin menurun.

\section{Warna}

Hubungan antara lightness dan ${ }^{\circ} \mathrm{Hue}$ terhadap warna yoghurt susu kuda liar Sumbawa dapat dilihat pada Gambar 4 dan Gambar 5. Gambar 4 menunjukkan bahwa konsentrasi ekstrak kayu manis memberikan pengaruh yang berbeda nyata terhadap kadar protein yoghurt susu kuda liar Sumbawa dengan pola regresi linear dengan persamaan $y=-268,7 x+66,12$ dengan koefisien determinan $\left(R^{2}\right)=0,781$. Nilai $-268,7$ menunjukkan arah regresi linear yaitu nilai negatif. Nilai negatif pada pola regresi menunjukkan hubungan yang negatif antara 
perlakuan konsentrasi ekstrak kayu manis dengan nilai lightness yoghurt susu kuda liar Sumbawa yang dihasilkan. Hal ini menunjukkan bahwa ekstrak kayu manis dengan konsentrasi tertentu, maka nilai lightness yoghurt susu kuda liar Sumbawa dapat semakin menurun. Nilai 66,12 menunjukkan konstanta, sehingga pada nilai (x) atau konsentrasi ekstrak kayu manis $=0$, maka warna (lightness) yoghurt susu kuda liar Sumbawa adalah sebesar $66,12 \%$. Nilai koefisien determinan $\left(R^{2}\right)$ diperoleh sebesar 0,781 yang berarti bahwa $78,1 \%$ warna yoghurt susu kuda liar Sumbawa dipengaruhi oleh adanya konsentrasi ekstrak kayu manis dan sebagian kecil yaitu sebesar 21,9\% merupakan faktor lain yang mempengaruhi warna yoghurt susu kuda liar Sumbawa.

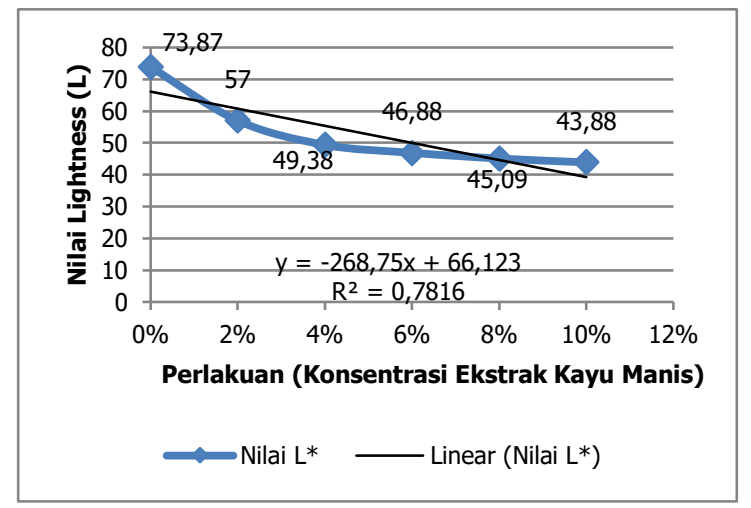

Gambar 4. Grafik Pengaruh Konsentrasi Ekstrak Kayu Manis terhadap Nilai Lightness (L)Yoghurt Susu Kuda Liar Sumbawa

Gambar 5 menunjukkan bahwa terjadi penurunan nilai lightness dari konsentrasi $0 \%$ hingga $10 \%$. Pada konsentrasi $0 \%$ (kontrol) menunjukkan nilai lightness sebesar 73,87 , sedangkan nilai terendah ialah pada konsentrasi $10 \%$ yaitu sebesar 43,88 . Semakin meningkat konsentrasi ekstrak kayu manis yang ditambahkan maka yoghurt susu kuda liar yang dihasilkan menunjukkan warna yang cenderung lebih gelap yang ditandai dengan semakin kecilnya nilai $L^{*}$. Hal ini erat kaitannya dengan adanya kandungan senyawa sinemaldehid pada kayu manis. Menurut Hastuti dan Rustanti (2014) mengungkapkan bahwa komponen utama pada kayu manis berupa sinemaldehid. Sinemaldehid adalah senyawa turunan aldehid yang termasuk dalam senyawa metabolid sekunder golongan polifenolat. Sinemaldehid adalah salah satu komponen penyusun minyak atsiri yang terdapat dalam kulit batang kayu manis. Senyawa ini terdapat dalam kayu manis dengan kandungan hampir 84\% (Astri, 2017). Sinemaldehid selain bersifat antioksidan juga berperan sebagai pemberi aroma dan warna pada minuman. Semakin banyak penambahan kayu manis pada produk, maka warna yang dihasilkan semakin gelap karena sinemaldehid yang larut semakin banyak.

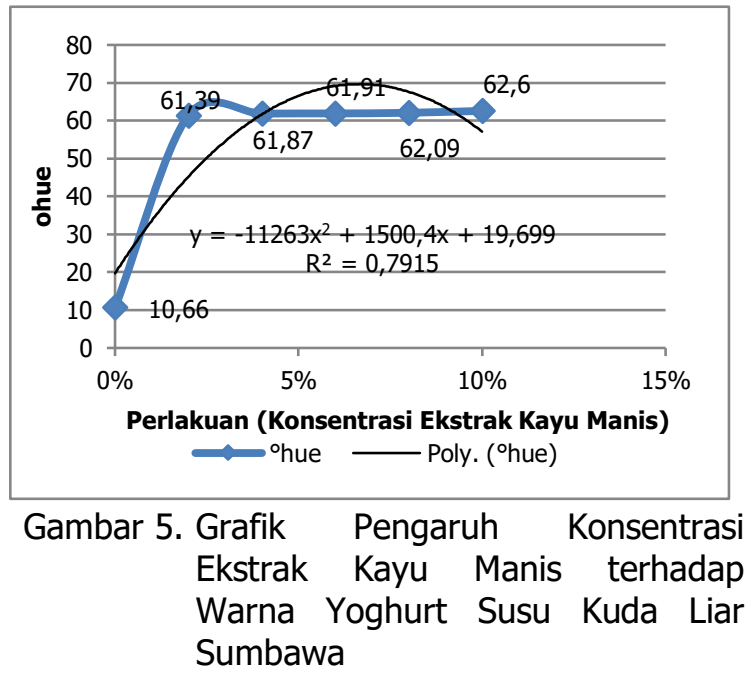

Gambar 5 menunjukkan bahwa konsentrasi ekstrak kayu manis memberikan pengaruh yang berbeda nyata terhadap kadar protein yoghurt susu kuda liar Sumbawa dengan pola regresi linear dengan persamaan $y=-11263 x^{2}+1500 x+19,69$ dengan koefisien determinan $\left(R^{2}\right)=0,791$. Nilai 11263 menunjukkan arah regresi linear. Nilai positif pada pola regresi menunjukkan hubungan yang positif antara perlakuan konsentrasi ekstrak kayu manis dengan warna yoghurt susu kuda liar Sumbawa yang dihasilkan. Hal ini menunjukkan bahwa ekstrak kayu manis dengan konsentrasi tertentu, maka warna yoghurt susu kuda liar Sumbawa dapat semakin tinggi. Nilai 19,69 menunjukkan konstanta, sehingga pada nilai $(x)$ atau konsentrasi ekstrak kayu manis $=0$, maka warna ( ${ }^{\circ} \mathrm{Hue}$ ) yoghurt susu kuda liar Sumbawa adalah sebesar 19,69\%. Nilai koefisien 
determinan $\left(R^{2}\right)$ diperoleh sebesar 0,791 yang berarti bahwa $79,1 \%$ warna yoghurt susu kuda liar Sumbawa dipengaruhi oleh adanya konsentrasi ekstrak kayu manis dan sebagian kecil yaitu sebesar 20,9\% merupakan faktor lain yang mempengaruhi warna yoghurt susu kuda liar Sumbawa.

Gambar 5 menunjukkan bahwa terjadi peningkatan warna ( $\left.{ }^{\circ} \mathrm{Hue}\right)$ dari konsentrasi $0 \%$ hingga $10 \%$. Pada konsentrasi $0 \%$ (kontrol) menunjukkan ${ }^{\circ}$ Hue sebesar $11^{\circ}$ yang apabila dilihat pada tabel kisaran warna kromatis menunjukkan warna "putih" yang sesuai dengan warna dari bahan dasar pembuatan yoghurt susu kuda liar Sumbawa yaitu berwarna putih, sedangkan pada perlakuan konsentrasi $2 \%$ hingga $10 \%$ menunjukkan ${ }^{\circ}$ Hue yang berkisar antara $61^{\circ}-$ $62^{\circ}$ yang apabila dilihat pada tabel kisaran warna kromatis menunjukkan warna "kuningmerah". Perbedaan warna ini diakibatkan oleh kandungan sinemaldehid pada kayu manis yang berwarna kekuningan. Semakin banyak penambahan kayu manis warna yang dihasilkan semakin mendekati merah tua atau kecokelatan (Ni`ma, 2010).

\section{Total BAL}

BAL merupakan mikroorganisme yang berperan penting dalam pembuatan yoghurt. BAL akan tumbuh dan menghasilkan asam laktat yang akan memberikan rasa dan aroma khas pada yoghurt. Hubungan antara total BAL yoghurt susu kuda liar Sumbawa dengan konsentrasi ekstrak kayu manis dapat dilihat pada Gambar 6.

Gambar 6 menunjukkan bahwa terjadi peningkatan total BAL sejalan dengan peningkatan konsentrasi ekstrak kayu manis yang ditambahkan. Total BAL tertinggi diperoleh pada perlakuan konsentrasi ekstrak kayu manis dengan konsentrasi $10 \%$ yaitu sebesar $8,2 \times 10^{9} \mathrm{CFU} / \mathrm{ml}$ dan total BAL terendah ialah pada perlakuan kontrol $(0 \%)$ yaitu sebesar $4 \times 10^{7} \mathrm{CFU} / \mathrm{ml}$.

Meningkatnya total BAL sejalan dengan semakin tinggi konsentrasi ekstrak kayu manis yang ditambahkan, yang berkaitan dengan penurunan $\mathrm{pH}$ yoghurt susu kuda liar
Sumbawa. Hal ini disebabkan karena ekstrak kayu manis memiliki pH 4,25 yang berasal dari senyawa kimia berupa sinemaldehid yang bersifat asam, sehingga penambahan dengan konsentrasi yang semakin tinggi akan memberikan suasana yang semakin asam (Hastuti dan Rustanti, 2014). Hal ini sesuai dengan penelitain Rizal dan Tria (2013) yang menyatakan bahwa sinemaldehid memiliki senyawa turunan berupa asam organik yaitu asam sinamat yang dapat berperan dalam menurunkan $\mathrm{pH}$, sehingga semakin tinggi konsentrasi maka dapat memberikan lingkungan yang sesuai dengan kondisi optimal pertumbuhan BAL. Dengan demikian, semakin tinggi konsentrasi ekstrak kayu manis yang ditambahkan maka total BAL yoghurt susu kuda liar Sumbawa yang dihasilkan semakin meningkat. Berdasarkan Gambar 21, terlihat bahwa total BAL yoghurt susu kuda liar Sumbawa dengan konsentrasi ekstrak kayu manis sebesar $0 \%$ hingga $10 \%$ memenuhi syarat menurut Standar Nasional Indonesia (SNI) nomor (SNI) 2981:2009 yang menyatakan bahwa total BAL minimal untuk produk yoghurt ialah sebesar $10^{7} \mathrm{koloni} / \mathrm{g}$.

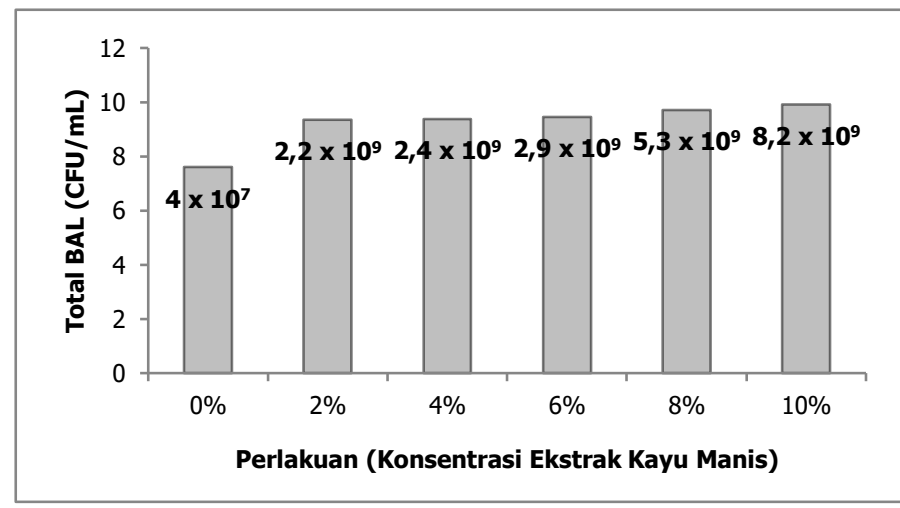

Gambar 6. Grafik Pengaruh Konsentrasi Ekstrak Kayu Manis terhadap Total BAL Yoghurt Susu Kuda Liar Sumbawa

\section{Aroma (Hedonik)}

Cita rasa dan aroma timbul karena adanya senyawa kimia alamiah maupun sintetik dan reaksi senyawa kimia dengan ujung-ujung syaraf indera lidah dan hidung. Penilaian aroma dilakukan dengan menggunakan alat indera penciuman dengan 
menangkap senyawa volatil atau senyawa yang mudah menguap yang terdapat pada produk (Stefani, 2008). Hubungan ekstrak kayu manis terhadap aroma yoghurt susu kuda liar Sumbawa dapat dilihat pada Gambar 7.

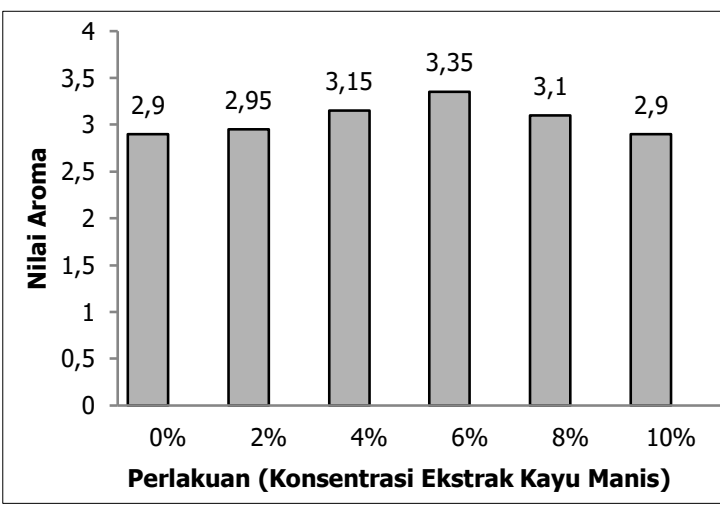

Gambar 7. Grafik Pengaruh Konsentrasi Ekstrak Kayu Manis terhadap Aroma (Hedonik) Yoghurt Susu Kuda Liar Sumbawa

Gambar 7 menunjukkan bahwa tingkat kesukaan (hedonik) penilaian panelis terhadap aroma yoghurt susu kuda liar Sumbawa yang dihasilkan berkisar antara 2,9 - 3,35 (agak suka), dengan nilai tertinggi yaitu pada perlakuan konsentrasi ekstrak kayu manis sebanyak $6 \%$ dengan nilai sebesar 3,35 (agak suka), dan nilai terendah ialah pada konsentrasi $0 \%$ dan $10 \%$ dengan nilai 2,9 (agak suka). Hal ini disebabkan karena konsentrasi ekstrak kayu manis yang ditambahkan memberikan aroma khas yang mampu menutupi aroma khas asam yoghurt hasil fermentasi. Hal ini sesuai dengan penelitian Anggraini, dkk (2015) yang menyatakan bahwa kandungan kimia dalam ekstrak kayu manis seperti sinemaldehid dan eugenol menyebabkan aroma khas kayu manis pada suatu minuman. Semakin tinggi konsentrasi ekstrak kayu manis yang ditambahkan maka aroma yoghurt susu kuda liar Sumbawa semakin beraroma khas kayu manis dan tidak mengurangi kesukaan panelis terhadap yoghurt yang dihasilkan.

\section{Rasa (Hedonik)}

Rasa makanan dapat dikenali dan dibedakan oleh kuncup-kuncup cecapan yang terletak pada papilla yaitu noda merah jingga pada lidah. Faktor yang mempengaruhi rasa yaitu senyawa kimia, suhu, konsistensi dan interaksi pangan dengan komponen rasa yang lain serta jenis dan lama pemasakan. Hubungan ekstrak kayu manis terhadap rasa yoghurt susu kuda liar Sumbawa dapat dilihat pada Gambar 8.

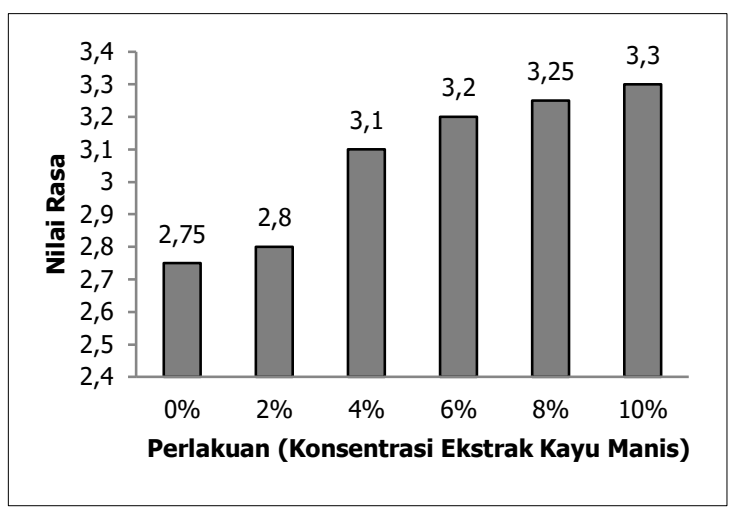

Gambar 8. Grafik Pengaruh Konsentrasi Ekstrak Kayu Manis terhadap Rasa (Hedonik) Yoghurt Susu Kuda Liar Sumbawa

Gambar 9 menunjukkan bahwa tingkat kesukaan (hedonik) penilaian panelis terhadap rasa yoghurt susu kuda liar yang dihasilkan berkisar antara 2,75 - 3,3 (agak suka), dengan nilai tertinggi yaitu pada perlakuan konsentrasi ekstrak kayu manis sebanyak $10 \%$ dengan nilai sebesar 3,3 (agak suka), dan nilai terendah ialah pada konsentrasi $0 \%$ (agak suka). Hal ini disebabkan karena rasa asam sebagai rasa khas susu fermentasi dapat disamarkan oleh rasa khas kayu manis yang disebabkan oleh adanya kandungan senyawa berupa sinemaldehid dan eugenol yang terdapat dalam kayu manis sehingga meningkatkan kesukaan panelis pada yoghurt susu kuda liar Sumbawa yang dihasilkan, sehingga semakin tinggi konsentrasi ekstrak kayu manis yang ditambahkan maka rasa yang ditimbulkan agak berasa asam yang disukai oleh panelis. 


\section{KESIMPULAN}

1. Perlakuan konsentrasi ekstrak kayu manis memberikan pengaruh yang berbeda nyata terhadap aktivitas antioksidan, kadar protein, $\mathrm{pH}$, viskositas, warna, tetapi tidak berbeda nyata pada uji hedonik rasa dan aroma.

2. Semakin tinggi konsentrasi ekstrak kayu manis maka meningkatkan aktivitas antioksidan, kadar protein, warna, total $\mathrm{BAL}$, dan nilai hedonik tetapi menurunkan nilai $\mathrm{pH}$.

3. Perlakuan konsentrasi ekstrak kayu manis sebesar $10 \%$ direkomendasikan sebagai perlakuan terbaik pada proses pembuatan yoghurt susu kuda liar Sumbawa berdasarkan aktivitas antioksidan 35,76\%; kadar protein 3,85\%; pH yoghurt 4,65; viskositas 4.746,67 mPa.s; warna ('Hue) dan nilai lightness berturut-turut yaitu $62^{\circ}$ dan 43,88; serta jumlah total BAL $8,2 \times 10^{9}$ $\mathrm{CFU} / \mathrm{ml}$ serta mutu organoleptik yang dapat diterima oleh panelis.

\section{DAFTAR PUSTAKA}

Anggraini, D. T., W. Prihanta, dan E. Purwanti, 2015. Penggunaan Ekstrak Batang Kayu Manis (Cinnamomum burmanni) terhadap Kualitas Minuman Sari Buah Kelapa. Seminar Nasional XII. ISSN: 915 - 921.

Apriliani, R., Tamrin., Hermanto. 2019. Pengaruh Penambahan Kayu Manis (Cinnamomum verum) terhadap Karakteristik Organoleptik dan Antioksidan Minuman Sari Buah Alpukat (Perseaamericana mill). J. Sains dan Teknologi Pangan. 4(6):2621-2634

Astri, R. 2017. Analisis Komponen Kimia Minyak Atsiri Kulit Kayu Manis (Cinnamomum burmannii) serta Uji Aktivitas Antioksidan dan Antibakteri. Skripsi. Universitas Sumatera Utara Medan

Badan Pusat Statistika, 2014. Jumlah Kuda Sumbawa di Kabupaten Sumbawa. Badan Pusat Statistika. Jakarta.
Bandara T., 2011. Bioactivity of Cinnamon with Special Emphasis on Diabetes Mellitus: A review. International Journal of Food Sciences and Nutrition. 1 - 7

Fardiaz, S., 1993. Analisis Mirobiologi Pangan. Raja Grafindo Persada, Jakarta.

Hasan, NF. 2011. Chemical Composition and Biological Activity of Essential Oil From Cinnamomum spp. and Litsea spp. Dissertation. Faculty of Resource Science and Technology. Universiti Malaysia Sarawak.

Hastuti, A. M., dan N. Rustanti, 2014. Pengaruh Penambahan Kayu Manis Terhadap Aktivitas Antioksidan dan Kadar Gula Total Minuman Fungsional Secang dan Daun Stevia sebagai Alternatif Minuman Bagi Penderita Diabetes Melitus Tipe 2. Journal of Nutrition College. 3 (3) : 362 - 369.

Herawati, D. A., dan A. A. Wibawa, 2011. Pengaruh Konsentrasi Susu Skim dan Waktu Fermentasi terhadap Hasil Pembuatan Soygurt. Jurnal IImiah Teknik Lingkungan. 1 (2): 48 - 50.

Indratiningsih, Widodo, S. I. O. Salasia, dan E. Wahyuni. 2004. Produksi Yoghurt Shiitake (Yoshitake) sebagai Pangan Kesehatan Berbasis Susu. Jurnal Teknologi dan Industri Pangan. 15 (1): 54-60.

Legowo, A. M., S. Mulyani dan Kusrahayu, 2009. Teknologi Pengolahan Susu. Universitas Diponegoro. Semarang.

Lindasari, F., R. R. A. Maheswari, A. Atabany., dan M. S. Soenarno, 2013. Karakteristik Yoghurt Probiotik Ekstrak Kayu Manis dari Susu Kambing Hasil Fermentasi Pakan Campuran Garam Karboksilat Kering. Jurnal IImu Produksi dan Teknologi Peternakan. 1 (2) : 80 - 87.

Ni`ma, EN. 2010. Pemisahan Sinamaldehid dari Minyak Kulit Batang Tumbuhan Kayu Manis (Cinnamomum burmanni) dengan Pereaksi Natrium Bisulfit. Skripsi. Universitas negeri Yogyakarta Yogyakarta

Percival, M., 1998. Antioxidants. Journal Clinical and Nutrition Insight. 1 - 4.

Purwitasari, E., Pangastuti, A., dan Setyaningsih, R. 2004. Pengaruh Media 
Tumbuh terhadap Kadar Protein Saccharomyces cerevisiae dalam Pembuatan Protein Sel Tunggal. Bioteknologi, 1 (2): 37-42

Putri, S.S. 2018. Pengaruh Penambahan Bubuk Kulit Kayu Manis (Cinnamomum burmanii) terhadap Aktivitas Antioksidan, pH, Viskositas, Nilai Organoleptik dan Total Koloni Bakteri Asam Laktat Mayonnaise Kuning Telur Probiotik. Skripsi. Universitas Andalas. Sumatera Barat.

Rachman, A., Fardiaz, S., Rahayu, W.P., Suliantari, Nurwitri, C.C. 1992. Teknologi Fermentasi Susu. Departemen Pendidikan dan Kebudayaan. Ditjen Pendidikan Tinggi PAU-Pangan dan Gizi. Institut Pertanian Bogor.

Setiarto R. H. B., N Widhyastuti, dan I. Fairuz, 2017. Pengaruh Starter Bakteri Asam Laktat dan Penambahan Tepung Talas Termodifikasi Terhadap Kualitas Yoghurt Sinbiotik. Jurnal Riset Teknologi Industri. 11 (1): 18 -30.

Shah, N. P., 2000. Symposium: Probiotic bacteria. Probiotik Bacteria: Selective Enumeration and Survival in Diary Foods. Journal Dairy Science. 8 (3): 894 - 907.

Shan B, Y. Z. Cai, J. D. Brooks, dan H. Corke, 2007. Antibacterial Properties and Major Bioactive Components of Cinnamon Stick (Cinnamomum Burmannii): Activity Against Foodborne Pathogenic Bacteria. Journal of Agricultural and Food Chemistry. 55 (14): 5484 - 5490.

Sudarmadji, S., Haryono, dan Supardi, 2007. Analisis Bahan Makanan dan Pertanian. Liberty.Yogyakarta.

Surajudin, R., K. Fauzi dan D. Purnomo, 2005. Yoghurt Susu Fermentasi yang Menyehatkan. Agromedia Pustaka. Jakarta.

Susilorini, T. E., dan M. E. Sawitri, 2007. Produk Olahan Susu. Penebar Swadaya. Jakarta.

Tandrianto, J., D. K. Mintoko dan S. Gunawan, 2014. Pengaruh Fermentasi Pada Pembuatan Mocaf (Modified Cassava Flour) dengan Menggunakan Ragi Roti (Saccharomyces cereviseae), Ragi Tempe (Rhizopus oryzae), dan
Lactobacillus plantarum Terhadap Kandungan Zat Nutrisi dan Anti Nutrisi. Skripsi. Institut Teknologi Sepuluh November. Surabaya.

Towaha, J. 2012. Manfaat Eugenol Cengkeh dalam Berbagai Industri di Indonesia. Perspektif. 11 (2): 79 - 90

Whitaker, J. R., dan S. R. Tannenbaum, 1977. Food Protein. AVI Publishing Company, Inc. Westport. Connecticut.

Winarno, F. G. 1997. Kimia Pangan dan Gizi. Gramedia Pustaka Utama. Jakarta.

Winarno, F.G., dan I.E. Fernandez, 2007. Susu dan Produk Fermentasinya. M-BRIO PRESS. Bogor. 